\title{
Announcement
}

\section{Postgraduate Videotape Programs in Diagnostic Radiology}

The Department of Radiology, University of California San Francisco, has developed 15 postgraduate videotape programs in all aspects of diagnostic radiology. An outstanding group of national and international guest lecturers, in addition to the staff at the University of California, present basic approaches to radiographic interpretation and technique as well as new research and clinical advances.

The following courses are presently available on videotape:

1. Neuroradiology Didactic Lectures -25 hours

2. Practical Problems in Clinical Neuroradiology -25 hours

3. Computerized Tomographic Brain Scanning-25 hours

4. Technical Aspects of Radiology-12 hours

5. Computerized Tomographic Body Scanning -12 hours

6. Practical Problems in Clinical CT Body Scanning-12 hours

7. Gastrointestinal Radiology -25 hours

8. Thoracic Radiology -12 hours

9. Cardiac Radiology -12 hours
10. Pediatric Radiology -12 hours

11. Uroradiology -12 hours

12. Skeletal Radiology - 12 hours

13. Diagnostic Ultrasonography -12 hours

14. Nuclear Medicine-10 hours

15. 19th Annual University of California Postgraduate Course in Diagnostic Radiology 1976-25 hours

This program has been accepted by the AMA and CMA for Category I credit.

For further information, please write to:

Aveleen Blumenstock

Videotape Coordinator

Department of Radiology

University of California San Francisco

San Francisco, California 94143

(telephone: area code 415-666-1988)

Overseas distribution is available as well.

\section{Erratum}

In the article in the last issue (Vol. 1, No.2, 1976, pp. 103-108) entitled "The Bone Marrow Scan in Experimental Osteomyelitis" by Dr. D.S. Feigin etal., the institutional designation below the authors' names was incorrectly published. It should have read as follows:
Department of Radiology and Radiological Sciences, The Johns Hopkins Medical Institutions, Baltimore, Maryland, USA.

The address for reprint requests remains unchanged. The publisher apologizes for any inconvenience or embarrassment that this may have caused the authors.

Responsible for the text: Jack Edeiken, M.D., Philadelphia; Harold G. Jacobson, M.D., Bronx; Ronald O. Murray, M.D., London

For advertisements: L. Siegel, E. Lückerman, Kurfürstendamm 237, D-1000 Berlin 15

Printed in Germany by Universitätsdruckerei H. Stürtz AG, D-8700 Würzburg. - (C) 1977 by the International Skeletal Society 